\title{
Transient sexual precocity and ovarian cysts
}

\author{
A J LYON, R DE BRUYN, AND D B GRANT \\ Hospital for Sick Children, Great Ormond Street, London
}

SUMmARY Nine girls presenting under the age of 7 years with unsustained sexual precocity are described. Large ovarian cysts were detected by ultrasound in three and laparotomy in one. In two girls the symptoms resolved after surgical removal of the cyst; the other seven had spontaneous remission of symptoms, but in two of these transient breast development and bleeding recurred: further ovarian cyst formation was found in one of these patients. Endocrine studies performed before resolution of the cysts showed raised plasma oestradiol concentrations (64 to $440 \mathrm{pmol} / \mathrm{l}$ ) in three girls and no appreciable rise in plasma luteinising hormone after gonadotrophin releasing hormone stimulation in two.

We conclude that ovarian cyst formation with spontaneous resolution may cause transient sexual precocity in girls, and that ultrasound examination is an effective means of diagnosing and following these patients.

Transient breast enlargement and menstrual bleeding-sometimes recurring at irregular intervals -without progression into puberty has been described in prepubertal girls. ${ }^{1}$ Apart from cases due to ingestion of oestrogen, the aetiology of this condition is uncertain, although there is evidence from patients undergoing laparotomy that formation of large follicular cysts of the ovary may underlie the disorder. ${ }^{2} 3$

We review the clinical, endocrine, and ultrasound findings in nine girls who were seen because of transient breast development occurring before the age of 7 years.

\section{Patients and findings}

Nine girls with transient breast development were seen between 1973 and 1983. Five patients had recurrent symptoms; in four breast development occurred on two separate occasions and one girl had

Table Findings in nine girls with transient sexual precocity

\begin{tabular}{|c|c|c|c|c|c|c|c|c|c|}
\hline \multirow{3}{*}{$\begin{array}{l}\text { Case } \\
\text { no }\end{array}$} & \multirow{3}{*}{$\begin{array}{l}\text { Age at } \\
\text { onset } \\
\text { (yrs) }\end{array}$} & \multirow{3}{*}{$\begin{array}{l}\text { No of } \\
\text { episodes } \\
\text { of breast } \\
\text { development }\end{array}$} & \multirow{3}{*}{$\begin{array}{l}\text { History of } \\
\text { vaginal } \\
\text { bleeding }\end{array}$} & \multicolumn{4}{|c|}{ Laboratory investigations } & \multirow{3}{*}{$\begin{array}{l}\text { Examination } \\
\text { under } \\
\text { anaestheticl } \\
\text { surgical } \\
\text { findings }\end{array}$} & \multirow{3}{*}{$\begin{array}{l}\text { Ultrasound } \\
\text { findings }\end{array}$} \\
\hline & & & & \multirow[t]{2}{*}{ Age } & \multicolumn{2}{|c|}{ Peak after $L H R H$} & \multirow{2}{*}{$\begin{array}{l}E_{2} \\
(p m o l l l)\end{array}$} & & \\
\hline & & & & & $\begin{array}{l}L H \\
(U / l)\end{array}$ & $\begin{array}{l}F S H \\
(U / l)\end{array}$ & & & \\
\hline 1 & $2 \cdot 8$ & 1 & Yes & $\begin{array}{l}3 \cdot 0 \\
3 \cdot 3\end{array}$ & $\begin{array}{l}<1 \\
<1\end{array}$ & $\begin{array}{l}3 \cdot 8 \\
2 \cdot 7\end{array}$ & $\begin{array}{l}64 \\
180\end{array}$ & $\begin{array}{l}\text { Laparotomy. } \\
\text { Cystectomy. Theca } \\
\text { lutein cyst }\end{array}$ & $\begin{array}{l}\text { Left ovarian } \\
\text { cyst }\end{array}$ \\
\hline 2 & $4 \cdot 6$ & 3 & Yes & $\begin{array}{l}4 \cdot 6 \\
7 \cdot 0\end{array}$ & $\begin{array}{l}9 \cdot 5 \\
<1\end{array}$ & $\begin{array}{l}3 \cdot 9 \\
<1 \\
\end{array}$ & $\begin{array}{l}93 \\
440\end{array}$ & $\begin{array}{l}\text { Laparoscopy. Biopsy. } \\
\text { No abnormality seen }\end{array}$ & $\begin{array}{l}\text { Right ovarian } \\
\text { cyst }\end{array}$ \\
\hline 3 & $4 \cdot 2$ & 2 & Yes & $\begin{array}{l}4 \cdot 3 \\
6 \cdot 2\end{array}$ & $6 \cdot 0$ & $12 \cdot 7$ & $\begin{array}{l}<50 \\
360\end{array}$ & Not done & Left ovarian cyst \\
\hline 4 & $6 \cdot 5$ & 2 & Yes & 6.6 & $2 \cdot 0$ & $4 \cdot 7$ & 118 & Not done & Bilateral small cysts \\
\hline 5 & $4 \cdot 5$ & 1 & No & - & - & - & - & $\begin{array}{l}\text { Laparotomy. Biopsy. } \\
\text { No abnormality seen }\end{array}$ & Not done \\
\hline 6 & $5 \cdot 0$ & 1 & Yes & - & - & - & - & $\begin{array}{l}\text { Laparotomy. } \\
\text { Oophorectomy large } \\
\text { folicular cysts }\end{array}$ & Not done \\
\hline 7 & $5 \cdot 0$ & 2 & Yes & - & - & - & - & $\begin{array}{l}\text { No abnormality on } \\
\text { examination under } \\
\text { anaesthetic }\end{array}$ & Not done \\
\hline 8 & $4 \cdot 0$ & 2 & Yes & - & - & - & - & As above & Not done \\
\hline 9 & $6 \cdot 5$ & 1 & No & $6 \cdot 5$ & $11 \cdot 0$ & $4 \cdot 0$ & 114 & Not done & No abnormality seen \\
\hline
\end{tabular}


three well documented episodes of breast development. Seven of the patients had one or more episodes of vaginal bleeding.

Two girls seen before the routine use of ultrasound examination underwent laparotomy because of a suspected pelvic abnormality. In one, nothing abnormal was detected but in the other a large follicular cyst was found in the right ovary, which was removed together with the cyst: histological examination showed a normal ovary with multiple follicular cysts.

Five girls had pelvic ultrasound examinations. One was reported as normal and one had multiple small cysts in both ovaries. Three girls were found to have large ovarian cysts. The case histories of these three patients are summarised briefly below.
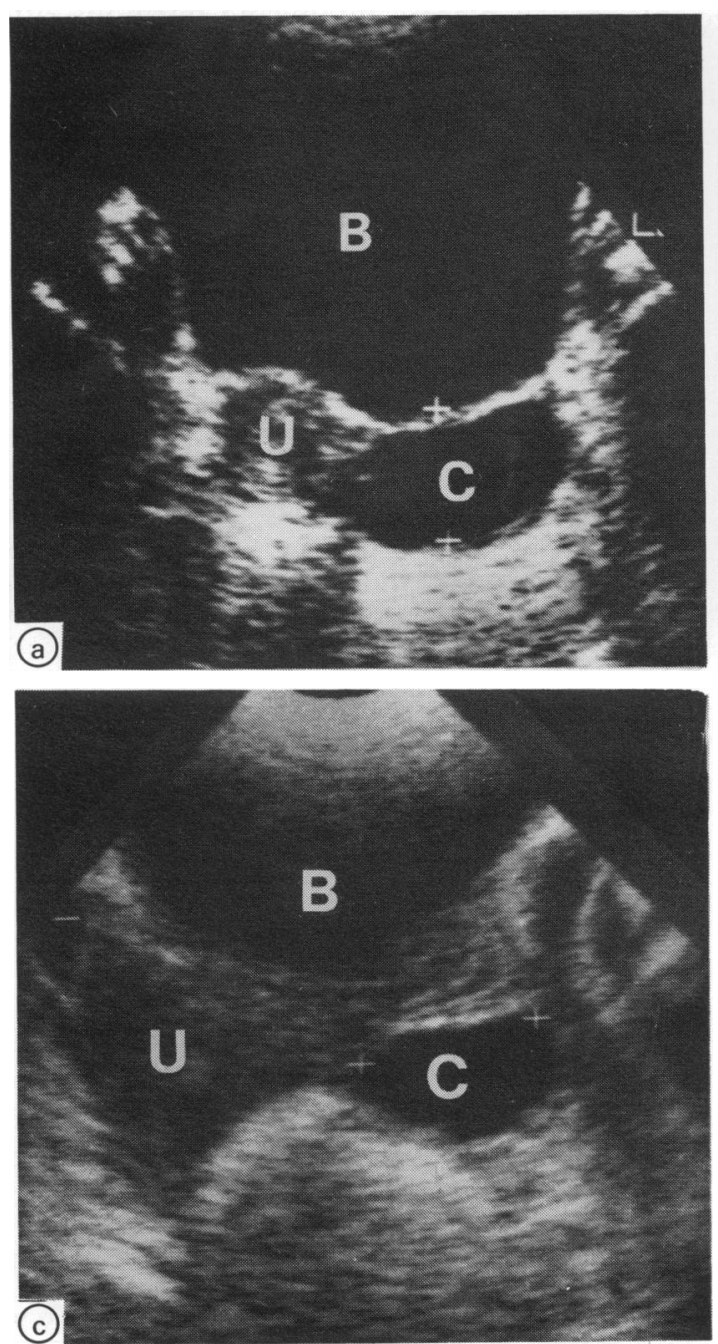

The Table gives the endocrine findings in five of these patients. Plasma luteinising hormone and follicle stimulating hormone were estimated by radioimmunoassay, ${ }^{4}$ as was plasma oestradiol. Plasma oestradiol was raised between $64 \mathrm{pmol} / \mathrm{l}$ and $440 \mathrm{pmol} / 1$ (normal prepubertal range less than $50 \mathrm{pmol} / \mathrm{l})$. After intravenous injection of $100 \mu \mathrm{g}$ gonadotrophin releasing hormone, peak luteinising hormone concentrations ranged from less than $1.0 \mathrm{U} / \mathrm{l}$ to $11.0 \mathrm{U} / \mathrm{l}$, and follicle stimulating hormone values from $1.0 \mathrm{U} / 1$ to $12.7 \mathrm{U} / 1$.

\section{Case reports}

Case 1. This girl was seen at the age of $2 \cdot 8$ years with a history of breast enlargement followed by blood

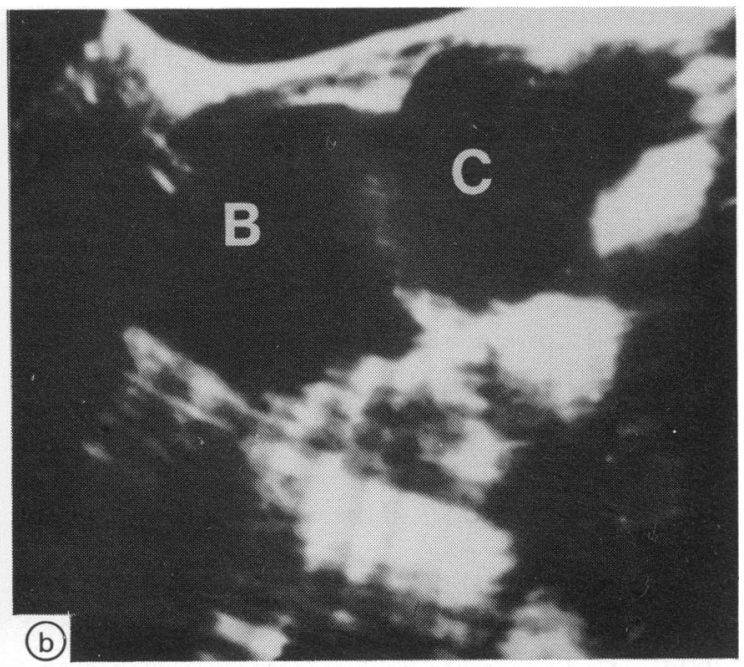

Figure Transverse ultrasound scan in (a) case 1, (b) case 2, and (c) case 3 .

$\mathrm{C}=$ cyst; $\mathrm{U}=$ uterus; and $\mathrm{B}=$ bladder. 
stained vaginal discharge. On examination she had stage 3 breast development (Tanner ${ }^{5}$ ) and some fine pubic hair. After intravenous injection of gonadotrophin releasing hormone there was no detectable rise in plasma luteinising hormone. Pelvic ultrasound showed a $2.0 \mathrm{~cm} \times 3.8 \mathrm{~cm}$ cystic lesion in the left ovary (Figure (a)). Repeat ultrasound at the age of 3.3 years showed that the cyst was unchanged in size. Plasma oestradiol was raised at $180 \mathrm{pmol} / \mathrm{l}$ and again there was no rise in plasma luteinising hormone after gonadotrophin releasing hormone stimulation. Laparotomy was performed and a follicular cyst removed from the left ovary. The signs of puberty rapidly resolved and ultrasound examination at the age of 4 years showed two normal prepubertal ovaries.

Case 2. This patient had an episode of blood stained vaginal discharge associated with swelling of her breasts at the age of 4.6 years. On examination she was noted to have stage 3 breast development but no other abnormality. Plasma oestradiol was slightly raised at $93 \mathrm{pmol} / \mathrm{l}$, and after injection of gonadotrophin releasing hormone plasma luteinising hormone rose to $9.5 \mathrm{U} / 1$ and follicle stimulating hormone to $3.9 \mathrm{U} / \mathrm{l}$. Laparoscopy showed a large right ovary; biopsy was reported as showing normal primordial follicles. Over the next four weeks her breasts regressed completely and the discharge stopped. At the age of 6.5 years, however, she had further breast enlargement and vaginal discharge. Plasma oestradiol was raised at $440 \mathrm{pmol} / \mathrm{l}$ and there was no appreciable plasma luteinising hormone or follicle stimulating hormone response to gonadotrophin releasing hormone. Ultrasound showed a large, mobile cyst of the right ovary (Figure (b)). Two weeks later she had vaginal bleeding for three days, after which the breast development regressed and the vaginal discharge stopped; the ovaries seemed normal on ultrasound. She remained symptom free until 8.4 years of age when she had further breast enlargement and vaginal bleeding; ultrasound was reported as showing a cyst in the right ovary but the symptoms settled rapidly and a repeat ultrasound at $8 \cdot 8$ years was normal. When last seen at the age of 12 years puberty seemed to be progressing normally and she had had no further bleeding: the ovaries were normal on ultrasound examination.

Case 3. This girl developed a clear vaginal discharge associated with breast enlargement when aged $4 \cdot 2$ years. Two weeks later she had vaginal bleeding for several days. After this her breast development regressed completely and the discharge stopped. Pelvic ultrasound examination at this time showed a completely normal prepubertal pattern. When aged 6.2 years she had recurrence of her breast enlargement and vaginal discharge. On examination she had stage 3 breast development and a mature vulval mucosa. Plasma oestradiol was $360 \mathrm{pmol} / \mathrm{l}$ and ultrasound examination showed an enlarged uterus and a $2.2 \mathrm{~cm} \times 2.7 \mathrm{~cm}$ cyst in the left ovary (Figure (c)). Two weeks later she had vaginal bleeding for one day, but after this the signs of puberty regressed and repeat ultrasound showed resolution of the ovarian cyst.

\section{Discussion}

Small follicular cysts, often multiple, are common findings in the ovaries of prepubertal girls, ${ }^{6}$ and in most cases they are of no clinical importance. Occasionally these cysts may enlarge and continue to produce oestrogen, resulting in signs of precocious sexual development and vaginal bleeding, the latter occurring as a withdrawal bleed when the cyst involutes. $^{23}$ The stimulus for follicle maturation is thought to be pulsatile secretion of pituitary gonadotrophins, which occurs even in the prepubertal period, ${ }^{7}$ but the mechanism underlying the formation of large follicular cysts is mainly unknown. Zipf et $a l^{8}$ have shown that the serum gonadotrophin response to gonadotrophin releasing hormone is suppressed in these patients, and our own findings are in general agreement with their observations. Two of our patients, who were investigated before resolution of their ovarian cysts, showed no appreciable rise in the plasma luteinising hormone concentration after gonadotrophin releasing hormone stimulation, in complete contrast with the increments in luteinising hormone values in girls with true precocious puberty. ${ }^{9}$ These findings strongly suggest that the formation of large follicular cysts of the ovary is not dependent on gonadotrophin secretion, unlike the seemingly normal ovarian development that occurs in true precocious puberty $^{10}$ as a result of pulsatile gonadotrophin secretion. .1 $^{11}$

The above case reports illustrate the value of ultrasound examination in detecting large ovarian cysts, which may not be palpable even under a general anaesthetic. This technique is now accepted as a safe and non-invasive means of examining the pelvis in young girls. ${ }^{12}$ The only technical requirement is that the patient has a full bladder, an 'acoustic window' to visualise the structures behind it. The uterus is pear shaped and easily identified; normal values for uterine size at different ages have been reported. ${ }^{13}$ The vagina is seen as echogenic lines parallel to the base of the bladder. Oestrogen secretion results in the lines becoming more promi- 
nent, probably as a result of thickening of the vaginal mucosa.

Ultrasound examination also provides a method of following the natural history of ovarian cysts. The findings in case 1 indicate that in some instances these cysts may persist almost unchanged for many months; we cannot say whether spontaneous involution would have occurred in this patient as surgery was performed after four months of observation. The findings in cases 2 and 3 , however, show that in some patients ovarian cysts can resolve only to recur with reappearance of symptoms. Obviously a normal ultrasound scan in such a case does not rule out the possibility that the symptoms of breast development were due to an ovarian cyst that had resolved by the time the patient was first seen, as we think may have occurred in some of the cases described above. Ultrasound examination is also of value in detecting ovarian tumours, another rare cause of precocious puberty. ${ }^{2}$ These are usually solid or mixed solid/cystic lesions, and can usually be distinguished from benign follicular cysts on ultrasound examination.

In view of the tendency for ovarian cysts to resolve spontaneously, we believe that surgery should be deferred for as long as possible, and only be carried out if there is doubt about the exact nature of the ovarian lesion. If a decision to excise the cyst is made, as much normal ovarian tissue as possible should be preserved at the time of operation.

We thank Dr Pierre Sizonenko for clinical and laboratory data in case 1 .

\section{References}

1 Richards GE, Kaplan SL, Grumbach MM. Sexual precocity caused by ovarian follicular cysts; spontaneous regression and recurrence with prepubertal gonadotropin levels. Pediatr Res 1977;11:431.

2 Eberlein WR, Bongiovanni AM, Jones TI, Yacouvac WC. Ovarian cysts and tumours associated with precocious puberty. $J$ Pediatr 1960;57:484-90.

3 Steiner MM, Hadawi SA. Sexual precocity associated with follicular cysts of ovary. Am J Dis Child 1964;108:28-36.

4 Savage MO, Preece MA, Cameron N, et al. Gonadotrophin response to LH-RH in boys with delayed growth and adolescence. Arch Dis Child 1981;56:552-6.

5 Tanner JM. Growth at adolescence. 2nd ed. Oxford: Blackwell, 1962.

6 Polhemus DW. Ovarian maturation and cyst formation in children. Pediatrics 1953;11:588-94.

7 Jacki RJ, Kelch RP, Sauder SE, Lloyd JS, Hopwood NJ, Marshall JS. Pulsatile secretion of luteinising hormone in children. J Clin Endocrinol Metab 1982;55:453-8.

${ }^{8}$ Zipf WB, Kelch RP, Hopwood NJ, Spencer ML, Bacon GE. Suppressed responsiveness to gonadotropin releasing hormone in girls with unsustained isosexual precocity. $J$ Pediatr 1979;95: 38-43.

9 Reiter EO, Kaplan SL, Conte FA, Grumbach MM. Responsivity of pituitary gonadotropes to luteinizing hormone-releasing factor in idiopathic precocious puberty, precocious thelarche, precocious adrenarche, and in patients treated with medroxyprogesterone acetate. Pediatr Res 1975;9:111-6.

10 Lyon AJ, De Bruyn R, Grant DB. Isosexual precocious puberty in girls. Acta Paediatr Scand 1985; in press.

11 Boyar RM, Finkelstein JW, David R, et al. Twenty-four hour pattern of plasma luteinizing hormone and follicle-stimulating hormone in sexual precocity. $N$ Engl J Med 1973;289:282-6.

12 Schneider M, Grossman H. Sonography of the female child's reproductive system. Pediatr Ann 1980;9:10-21.

${ }^{13}$ Ivarsson SA, Nilsson KO, Persson PH. Ultrasonography of the pelvic organs in prepubertal and postpubertal girls. Arch Dis Child 1983;58:352-4.

Correspondence to Dr D B Grant, Hospital for Sick Children, Great Ormond Street, London WC1N 3JH.

Received 2 April 1985 